\title{
NCoV-Based Considerations on Online- English Teaching and Traditional Classroom-English Teaching in China
}

\author{
Pan Cuiqiong \\ School of Foreign Studies of Yangtze University, China
}

Type of Work: Peer-Reviewed

DOl: http://dx.doi.org/10.21013/jems.v16.n2.p2

\begin{abstract}
How to cite this paper:
Cuiqiong, P. (2020). NCoV-Based Considerations on Online- English Teaching and Traditional Classroom-English Teaching in China. IRA International Journal of Education and Multidisciplinary Studies (ISSN 2455-2526), 16(2), 96-101. doi: http://dx.doi.org/10.21013/jems.v16.n2.p2
\end{abstract}

(C) Institute of Research Advances.

This work is licensed under a Creative Commons Attribution-Non Commercial 4.0 International License subject to a proper citation to the publication source of the work.

Disclaimer: The scholarly papers as reviewed and published by the Institute of Research Advances (IRA) are the views and opinions of their respective authors and are not the views or opinions of the IRA. The IRA disclaims of any harm or loss caused due to the published content to any party.

Institute of Research Advances is an institutional publisher member of Publishers International Linking Association Inc. (PILA-CrossRef), USA. The institute is an institutional signatory to the Budapest Open Access Initiative. Hungary advocating the open-access of scientific and scholarly knowledge. The Institute is a registered content provider under Open Access Initiative Protocol for Metadata Harvesting (OAI-PMH).

The journal is indexed \& included in WorldCat Discovery Service (USA), CrossRef Metadata Search (USA), WorldCat (USA), OCLC (USA), Open J-Gate (India), EZB (Germany) Scilit (Switzerland), Airiti (China), Bielefeld Academic Search Engine (BASE) of Bielefeld University, Germany, PKP Index of Simon Fraser University, Canada. 


\begin{abstract}
Facing the Novel Coronal Virus (NCoV) in China, teachers, and students are required to realize the idea "Class-stop means not stopping learning" so that all schools in China start the online teaching. This paper, from the view of $\mathrm{NCoV}$, based on the educational principles and features of online English teaching and traditional classroom English teaching, contrastively discusses what goes on in these two teaching ways and attempts to prove that online English teaching is only used as a kind of teaching aids and cannot be considered as the equal status as the classroom English teaching, which may offer the sign both for design the teaching software and for the reform of our country's education system.
\end{abstract}

Keywords: Online English teaching, Classroom English Teaching, a contrastive study

At present because of the Novel Coronal Virus (NCoV) in China, to realize the idea "Class-stop means not stopping learning", all schools start the online teaching, no matter what the school stage is and no matter which course it is. It's no doubt that we can't let NCoV prevent our students from learning. But according to teaching ideology and learning nature, online teaching is not an effective way to realize our educational goals, especially online English teaching. Online teaching now is just a kind of measure of expediency.

Thus, this paper, from the view of $\mathrm{NCoV}$, based on the educational principles and features of the two ways, contrastively discusses what goes on in the Online-English Teaching and Traditional Classroom-English teaching and attempts to prove that online English teaching is only used as a kind of teaching aids and cannot be considered as the equal status as the classroom English teaching, which may offer the sign for the reform of our country's education system.

\title{
1. Main concepts' interpretation
}

1) Online teaching and online English teaching

Online teaching is a process in which teachers employ the online software to teach the students who are not in the classroom and here we focus on the online teaching at home or somewhere covered by Network because of NCoV in China. Nowadays, the software like QQ-online, Rain-Classroom, and Tencent Meeting is used by teachers who are not in the classroom facing their students which occurs normally in the traditional classroom teaching.

Thus, Online English teaching refers to the process in which English teachers employ one of the software to teach their English courses to the students who are not in the classroom, instead of who is at home or somewhere else.

2) Educational principles

Among educational principles, how to be a good teacher and how to be a good learner are the most worthwhile standards in the teaching field.

So far as the question of how to be a good teacher, normally those "who care more about their students' learning than they do about their teaching" (Harmer, J, 2000:3) are good teachers. And the method teachers talk to or interact with students is one of the crucial skills for teachers. Good 
teachers not only use their right voice but also physical movement like gestures, expressions, eye-contacts, mime, etc in their teaching, which means that good teachers in the process of teaching, can empathize with students.

Then a good learner may have some or all of characteristics like a willingness to listen, to experiment, to ask questions, to think about how to learn, to accept correction (Harmer, J, 2000).

Only when teachers and students behave like the above principles can our educational goal be achieved and the class can be called a successful one.

\section{Features of Online and Classroom English teaching}

From Section 1, we may find out that online English teaching and classroom English teaching are two ways in teaching, but they have their features in teaching which determine the quality of the teaching. Some are similar and some are different. These features can be illustrated in Table 1 .

Table 1 Features of Online and Classroom English Teaching

\begin{tabular}{|c|c|c|}
\hline Items of features & Online English Teaching & Classroom English Teaching \\
\hline Teaching place & At home or somewhere else & Classroom \\
\hline Seating & Individuals & $\begin{array}{l}\text { Orderly rows, circles, horseshoes, } \\
\text { individuals }\end{array}$ \\
\hline Interacting & Voice and writing & Voice, writing, physical movement \\
\hline Teaching activities & Individual work, whole-class work & $\begin{array}{l}\text { Individual work, pair work, group } \\
\text { work, whole class work }\end{array}$ \\
\hline Teaching aids & Computer/mobile phone & $\begin{array}{l}\text { Chalk, blackboard, tables and } \\
\text { desks, PPT, computer, mobile } \\
\text { phone }\end{array}$ \\
\hline Teaching condition & With networks or Electricity & classroom \\
\hline
\end{tabular}

Note: PPP refers to Presentation, Practice, Production

Table 1 tells us some similarities and differences of the features of online teaching and classroom teaching and this directly affects some main elements in good teaching like roles of teacher and students, methods of problem-solving and results of teaching which will be discussed in the following part.

\section{A contrastive study between online English teaching and Classroom English teaching}

3.1 A contrastive analysis from three main elements in the teaching environment

It is known to us that in the teaching environment, the roles of teachers and students, methods for problem-solving between teachers and students, and the results of teaching are three main elements.

\section{1) Roles of teacher and students}

According to Section 1of the paper, we know both teachers and students have their responsibilities 
in having a class no matter which way they will be used to offer the class. However, in different teaching ways, the roles of teachers and students may differ in some way.

In the classroom teaching, the teacher acts as a controller, assessor, organizer, prompter, participant, and resource-provider (王蓄, 2000).To the students, they are the center in the class where they are engaged in teacher's teaching with interests and emotions, they are actively involved in what they are learning with questions and critical thinking on some language constructions, and they are activated by using language as freely and communicatively as they can. The interaction between teacher and students are various and timely as well that between students themselves.

However, about present online teaching, the teacher almost acts as a controller, and students are listening silently. Although the teacher may sometime stop lecturing and ask students some questions, few students may actively answer the questions because of the immature design of the teaching software. Meanwhile, sometimes the network doesn't go smooth so that students cannot be activated in what they are learning.

To sum up, if the roles of teachers and students cannot respond with the need in the educational policy, then it is hard to say it is a good class. Moreover, the interaction in online teaching is very limited so that the teacher cannot be a good teacher and the student can't be a good student.

\section{2) Methods for problems solving}

Teacher, as a professional title, is a person "who needs to advocate justice lessons, to teach professional knowledge and to solve tough problems". In a sense, solving any problems is the main task for teachers because justice lessons and professional knowledge can be both puzzled by students. At this point, teaching English can be more intricate for English teachers who should consider the mother language's transfer in students' English learning as well as problems in other aspects. Thus, the methods of problem-solving are very important in class. Naturally, different teaching ways may solve teaching problems differently.

In classroom teaching, the methods in solving problems depend on the class surrounding which refers to two items: students' behavior and students understanding.

When he or she observes students' behavior such as keeping quiet, bending their heads, shaking their heads, and looking at the teacher with puzzled eyes, the teacher may solve the problems in a way of controlling the lecture, explaining the solutions to the problems by himself or herself. When students offer some half-right answers or quite different answers, the teacher may organize discussions in a way of pair work, or group work or whole classwork.

However, about present online teaching, the methods in solving problems just depend on the corresponding voice from students or the questions on the writing board of the software. Although the teacher controls the class and explains the answers to the problems, he or she doesn't know whether the students understand or not because the teacher can't see the students at all.

In a word, if the teacher and students can't interact with each other, it is not a good English class 
and students' ability of solving problems by themselves can't be fostered in their lesson learning.

\section{3) Results of teaching}

Different teachers may get the same results of teaching, but different teaching ways must achieve different achievements because of their features and methods of problem-solving.

Traditional classroom teaching is the way in our full-time schooling education system and it is a disciplinary-governed schooling way for our people. This type of teaching way is always on the way of reform with the development of the economy and society. In a broad sense, the talents of generation and generation are being graduated from such kind of teaching way year by year. In a narrow sense, each student has the fair opportunity to be taught by the teacher, to show his or her creativity in class and to display the spirit of unity or cooperation with the others in the class.

Online teaching way is newly developed in our society and its wide usage is not so popular because of its limited functions and limited network system, especially online teaching in the situation of NCoV in China today. Maybe in a broad sense, this type of teaching way help teachers and students to understand the idea "class stop means not stopping learning" and help some students to solve the problems in studying, but clearly, it can't solve all students' problems because students' living environment is various, which means network, electricity, computer and mobile phone are necessary teaching aids in online teaching. In a narrow sense, an online English teaching way cannot make teachers design the proper teaching plan because online teaching way is not creating the situation of interaction between teacher and students. Meanwhile, teachers cannot assure that students concentrate on the class because teachers can't see students. Moreover, no pair work or group work prevents students from improving their abilities in English speaking and critical thinking, let alone the ability of cooperating with others.

In short, online teaching at present is just a tool for emergency and it can't achieve what our education system aims at. Yet, online teaching may be a good way for making reports or announcements.

\subsection{Implications of the two teaching ways}

English course is quite different from other courses because learning English aims to improve four skills like speaking, listening, writing and reading as well as translating and critical thinking(潘翠琼, 2012). Class performance by students is very crucial in students learning that cannot be realized in online teaching and this is the serious weak point to online teaching way.

Besides, in teaching principles, a completed class involves main six steps: lead-in, presentation, practice, discussion, summary, and critical thinking with assignments(潘翠琼, 2012). In each step the time-span and interaction between the teacher and students need proper design, which guarantees a proficient class. Here, from Section 3.1, although online English teaching covers the six steps, however, the teacher cannot achieve what he or she has expected because teaching activities should involve the efficient interaction between teacher and students, and this is not found in online teaching. Moreover, the time-span in online teaching is not feasible and manageable. 
Based on the former sections' discuss, some implications should be put forward:

1) Online teaching is acceptable only when teachers and students are in a very special time like today's Novel Coronal Virus to realize the idea "class stop means not stopping learning". In the educational principle, online teaching is not an efficient teaching way, especially online English teaching can be only a kind of teaching aids.

2) Online teaching software should be further improved imitating more features of classroom teaching if we want to use them in our class teaching. For example, it should let students not only see the teacher but also see their peers and vice versa. In this way, the interaction between teachers and students can be realized. This is very necessary in English learning or language learning classes.

3) Online teaching may offer some influence on our educational system's reform. Nowadays, Internet news reported that some schools or some teachers did very well in online teaching. If so, we need to think of some questions "Can we transfer some school buildings into other field functions because we need no more schools? Can we reduce some administrative officials in schools?" Of course, at present, we can't.

From this contrastive study, it is found that online teaching is only used as a kind of teaching aids because different stages of education and different courses have different goals of teaching and learning if the efficient teaching and learning is needed.

All the teachers and students need to go further thinking about how to make efficient and feasible use of online English teaching resources to reach our educational goal. Meanwhile, in the future with the well-designed development of high-tech teaching software, our country's education system should need to carry out a deeper revolution.

This is supported by the social science project of 2015 csy012 in Yangtze University, China.

\section{References}

[1]. Hermer, J. How to Teach English[M] Beijing: Foreign Language Teaching and Research Press 2000

[2]. 潘翠琼 Critical Thinking, Critical Thinking Teaching and Its Application [M] Wuhan: Hubei Education Press, 2012

[3]. 王蓄 A Course in English Language Teaching[M] Beijing: Higher Education Press, 2000 